ISSN. 2621-9832

JURNAL MathEdu (Mathematic Education Journal) http://journal.ipts.ac.id/index.php/MathEdu Vol. 4. No. 3 November 2021

\title{
UPAYA MENINGKATKAN MINAT BELAJAR SISWA MENGGUNAKAN MEDIA PEMBELAJARAN MATEMATIKA BERBASIS E-LEARNING
}

\author{
Oleh: \\ Nur Haminah Hasibuan', Erwina Azizah Hasibuan, ${ }^{2}$. Alvi Sahrin Nasution ${ }^{3}$ \\ ${ }^{1,2,3}$ Fakultas Keguruan dan Ilmu Pendidikan Universitas Graha Nusantara
}

\begin{abstract}
ABSTRAK
Penelitian ini adalah penelitian tindandakan kelas (Classroom Action Research), yaitu merupakan sebuah penelitian yang dilakukan oleh guru dikelasnya sendiri dengan merancang, melaksanakan, dan merefleksikan tindakan secara kolaboratif dan pastisipasif dengan tujuan untuk memperbaiki kinerja sebagai guru sehingga hasil belajar siswa meningkat. Adapun yang menjadi subjek dalam penelitian ini adalah siswa kelas X TkJ 1 SMK N 1 Batang Angkola Tahun Pelajaran 2020/2021 yang terdiri dari 30 orang siswa. Sedangkan objek dari penelitian ini adalah kemampuan meningkatkan hasil bejar siswa dalam menyelesaikan persoalan matematika, meningkatakan minat belajar siswa dan kemampuan guru mengelola pembelajaran melalui media e-learning. Hal ini dilihat dari hasil observasi siswa pada siklus I diperoleh persentase 56,3\% dengan kategori "Baik, selanjutnya persentase observasi siswa siklus II sebesar 75,56\% dengan kategori "Sangat Baik".2)Kemampuan hasil belajar siswa dalam pembelajaran matematika melalui media berbasiselearning siswa kelas X SMK N 1 Batang Angkola pada materi Trigonometri tahun pelajaran 2020/2021. Hal ini dapat ditunjukkan dengan persentase hasil tes belajar siswa matematika yaitu $43 \%$ dengan kategori "Cukup" pada siklus I menjadi 86\% dengan kategori "Baik" pada siklus II.3)Kemampuan guru dalam mengelola pembelajaran dengan menggunakan metode e-learning pada pokok bahasan Trigonometri di kelas X SMK N 1 Batang Angkola tahun pelajaran 2020/2021. Hal ini dilihat dari hasil observasi kemampuan guru dalam mengelola pembelajaran pada siklus I memperoleh persentase $83.33 \%$ dengan kategori "Baik" menjadi 95,83\% dengan kategori "Sangat Baik” pada siklus II.
\end{abstract}

\section{Keyword : Minat Belajar, Media Pembelejaran Matematika Berbasis E-Learning}

\section{PENDAHULUAN}

Rendahnya minat siswa pada pelajaran matematika dipandang perlu untuk melakukan evakuasi terhadap proses belajar mengajar dengan melihat sampai dimana tingkat keberhasilan siswa dalam kepercayaan diri siswa, melakukan refleksi dan perbaikan pada model dan strategi Pembelajaran. Sebagai pengelola pendidikan guru berkewajiaban untuk meningkatkan perhatian dan usaha yang sungguh-sungguh dalam memberikan pembelajaran khususnya pembelajaran disekolah, Sehingga pelajarannya dapat dipahami oleh siswa dan dapat mengacu kepada perkembangan pribadi pada siswa, Dengan tidak mengorbankan karakteristik matematika sebagai ilmu deduktif, abstrak dan konsisten. Menurut Erwina azizah (2016) Minat belajar matematika masih rendah, hal ini dikarenakan siswa tidak terbiasa menyelesaikan soal yang merupakan soal-soal yang berupa masalah yang berkaitan dengan kehidupan sehari-hari.Maka seseorang harus teliti dalam memilih strategi yang tepat atau sesuai dengan tujuan yang akan dicapai. Persoalan sekarang adalah bagaimana seorang guru yang baik dan bijaksana mampu menerapkan strategi pembelajaran yang berkaitan dengan percaya diri siswa ( Hanafia dan Suhana 2009).

Baru-baru ini proses belajar mengajar di Indonesia menjadi sedikit terganggu. Hal ini akaibat munculnya virus Covid 19atau yang lebih dikenal sebagai virus Corona di Indonesia. Virus ini pertama kali ditemukan di Wuhan, Cina pada bulan Desember 2019. Pada bulan Maret 2020 Indonesia mengumumkan kasus positif Covid 19yang pertama di Indonesia. Setelah kasus positif pertama tersebut, hampir setiap hari terjadi penambahan kasus positif Covid 19. Kondisini menjadi sangat meresahkan ketikdiketahui proses penularan Covid 19sangat cepat.tangan dan jaga jarak fisik atau yang Untuk mencegah penyebaran virus Covid 19 yang semakin meluas, maka dilakukan beberapa cara penanggulangan. Cara-cara tersebut adalah dengan menggunakan masker apabila keluar rumah, rajin mencuci sekarang lebih dikenal dengan Physical Distancing.Pemerintah juga menyarankan untuk melakukan banyak kegiatan dari rumah, salah satunya adalah belajar di rumah.

\section{METODE PENELITIAN}

Penelitian ini dilaksanakan di SMK Negeri 1 Batang Angkolapada kelas X tahun ajaran 2020/2021. Alasan peneliti memilih lokasi penelitian ini adalah karena belum ada penelitian sejenis di sekolah tersebut. 
ISSN. 2621-9832

JURNAL MathEdu (Mathematic Education Journal) http://journal.ipts.ac.id/index.php/MathEdu

Vol. 4. No. 3 November 2021

Penelitian ini di laksanakan setelah proposal di seminarkan pada prodi pendidikan matematika FKIP UGN. Penelitian ini di laksanakan pada semester genap tahun ajaran 2020/2021.

Subjek dalam penelitian ini adalah siswa Kelas X Tkj SMK Negeri Batang Angkola yang berjumlah 30 siswa 10 laki-laki dan 20 perempuan Tahun Ajaran 2020/2021. Objek penelitian ini adalah Upaya Meningkatkan minat siswa menggunakan media pembelajaran matematika berbasis E-learning Bagi Siswa Kelas X SMK Negeri 1 Batang Angkola Tahun Ajaran 2020/2021. Angket yang digunakan peneliti adalah angket minat belajar matematika dan angket respon siswa terhadap pembelajaran matematika menggunakan metode pembelajaran berbasis E-learning.

Tes yang diberikan kepada siswa dalam penelitian ini berupa tes hasil belajar dan tes meningkatkan Minat siswa. Dari tes tersebut akan dilihat dimana letak kesulitan siswa dan minat siswa supaya bisa disusun perencanan tindakan yang akan dilaksanakan dikelas tersebut. Dari tes yang dilakukan ini juga dapat dilihat apakah dengan media berbasis $E$-learning meningkatkan hasil belajar siswa dan meningkatkan kepercayaan diri siswa.

Jenis penelitian yang digunakan adalah metode Penelitian Tindakan Kelas (PTK), secara bersiklus terdiri dari perencanaan, Tindakan, Observasi, Dan refleksi. Penelitian ini diarahkan untuk memecahkan masalah atau perbaikan yang berhubungan dengan masalah-masalah dikelas. Menurut Rustam dan Mundilarto (2004: 1) mendefenisikan bahwa penelitian tindakan kelas adalah sebuah penelitian dilakukan oleh guru dikelasnya sendiri dengan jalan merancang, melaksanakan, nan merefleksikan tindakan secara kolaboratif dan partisipatif dengan tujuan untuk memperbaiki kinerjanya sebagai guru sehingga hasil belajar siswa dapat meningkat. Penelitian ini difokuskan kepada perbaikan proses maupun peningkatan hasil kegiatan. Setiap siklus terdiri dari empat tahap yang mengacu pada model Kurt Lewin yaitu rencana (planning), pelaksanaan tindakan (acting), Observasi (observing) dan refleksi (reflecting).

Hasil observasi proses pembelajaran adalah lembar observasi guru yang dapat dihitung dengan rumus:

$$
\mathrm{NP}=\frac{n}{N} \times 100 \%
$$

Keterangan:

$\mathrm{NP}=$ Persentase nilai hasil peserta didik yang diperoleh

$\mathrm{n}=$ Jumlah skor yang di peroleh

$\mathrm{N}=$ Jumlah skor maksimal

Nilai tersebut dimasukkan dalam kategori:

$86-95 \%=$ Sangat Baik

$66-75 \%=$ Baik

$56-65 \%=$ Cukup Baik

$40-55 \%=$ Kurang Baik

$\leq 39 \% \quad=$ Gagal

Indikator Keberhasilan

a. Meningkatnya minat belajar matematika siswa baik dari hasil angket dari siklus I ke siklus selanjutnya serta mencapai kriteria minimal 70\% yaitu kategori “baik"dari seluruh aspek yang diamati.

b. Meningkatnya skor rata-rata hasil belajar matematika siswa dilihat dari apabila rata-rata hasil belajar siswa meningkat dari hasil tes setelah siswa diberi tindakan mencapai Kriteria Ketuntasan Minimal (KKM) "75" yang telah ditetapkan sekolah dengan ketuntasan klasikal 70\% siswa memperolah nilai minimal "Baik" dari siswa yang mengikuti tes pada media pembelajaran maatematika berbasis $e$ learning pada meteri trigonometri di kelas kelas X Tkj Smk Negeri 1 Batang Angkola tahun ajaran $2020 / 2021$.

\section{HASIL PENELITIAN DAN PEMBAHASAN}

Deskripsi Pelaksanaan Penelitian ini dilaksanakan saat siswa sedang menghadapi pandemi Covid-19 dan siswa sedang melaksanakan pembelajaran online. Penelitian ini berlangsung selama satu minggu. Hasil penelitian tindakan siklus I diuraiakan dalam beberapa tahapan. Adapun tahapan yang dilakukan dalam proses Penelitian Tindakan Kelas (PTK) di kelas X Smk N 1 Batang Angkola dilaksanakan yaitu minat belajar siswa, tes tertulis dan observasi. Hasil penelitianminat belajar matematika siklus I diuraikan sebagai berikut: 
ISSN. 2621-9832

JURNAL MathEdu (Mathematic Education Journal) http://journal.ipts.ac.id/index.php/MathEdu

Vol. 4. No. 3 November 2021

Tabel 1 Angket Minat Belajar Matematika Siswa

\begin{tabular}{clccc}
\hline No & \multicolumn{1}{c}{ Alternatif Jawaban } & $\begin{array}{c}\text { Jumlah } \\
\text { Siswa }\end{array}$ & Persentase & Klasilifikasi Nilai \\
\hline 1 & Sangat Setuju (SS) & 13 & $50 \%$ & Sangat Baik \\
\hline 2 & Setuju (S) & 3 & $5 \%$ & Baik \\
\hline 3 & Tidak Setuju (TS) & 9 & $25 \%$ & Kurang \\
\hline 4 & Sangat Tidak Setuju (STS) & 5 & $20 \%$ & Sangat Kurang \\
\hline & Total & 30 & $100 \%$ & \\
\hline
\end{tabular}

Dari tabel 4.1 di atas, dari 30 siswa yang menjawab Sangat Setuju diperoleh 13 orang atau 50\% siswa dengan kategori "Sangat Baik", yang menjawab Setuju diperoleh 3 orang siswa atau 5\% dengan kategori " Baik", 9 orang siswa atau 25\% dengan kategori "Kurang", dan 5 orang siswa atau 20\% dengan kategori " Sangat Kurang". Namun peningkatan ini belum mencapai kriteria ketuntasan yang diharapkan, karena jumlah siswa yang memperoleh kategori minimal kurang sebanyak 9 orang siswa atau $25 \%$ dari 30 siswa yang menjawab tidak setuju, Sehingga belum sesuai dengan target yang telah di tetapkan $70 \%$ maka di adakan refleksi pada siklus berikutnya yaitu siklus II.

Untuk lebih jelasnya dapat dicermati grafik yang menggambarkan hasil angket minat belajar matematika siswa di siklus I sebagai berikut :

Grafik 1 Angket minat belajar matematika siswa siklus I

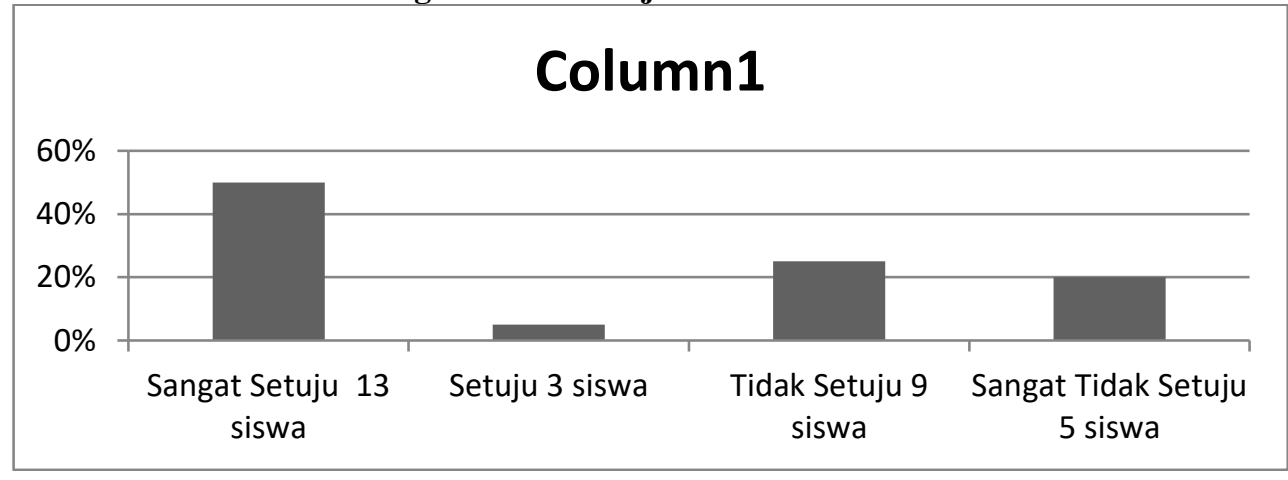

Hasil penelitian diuraiakan dalam tahapan yang berupa siklus-siklus pembelajaran yang dilakukan dalam proses belajran yang dilaksanakan di kelas X Tkj Smk N 1 Batang Angkola pada materi

Grafik 2 Hasil Tes Belajar Matematika Siswa

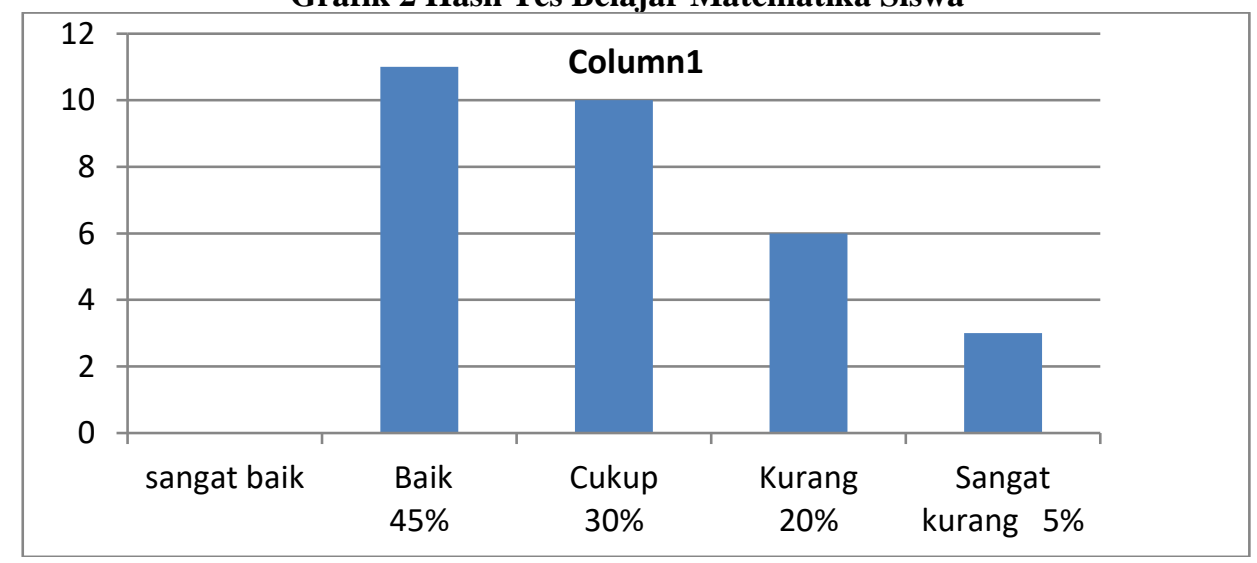

Dari Grafik 2 di atas dapat diketahui bahwa hasil belajar matematika siswa berada pada kategori "Cukup". Untuk itu perlu adanya perbaiki dan peningkatan pada proses pembelajaran siklus berikutnya atau pada siklus II. Diharapkan pada siklus berikutnya Minat siswa dan hasil belajar matematika siswa pada kategori "Sangat Baik" bertambah dan kategori "Sangat Kurang” mengalami penurunan. 
ISSN. 2621-9832

JURNAL MathEdu (Mathematic Education Journal) http://journal.ipts.ac.id/index.php/MathEdu Vol. 4. No. 3 November 2021

Hasil belajar siswa matematika siklus II dapat di klasifikasi sebagai berikut:

Tabel 2 Pengklasifikasian Nilai Hasil Tes Siklus II

\begin{tabular}{ccccc}
\hline No & $\begin{array}{c}\text { Tingkat } \\
\text { Kemampuan }\end{array}$ & Jumlah Siswa & Persentase & Kategori \\
\hline 1 & $90-100$ & 9 & $35 \%$ & Sangat Baik \\
\hline 2 & $80-89$ & 18 & $50 \%$ & Baik \\
\hline 3 & $65-79$ & - & - & Cukup \\
\hline 4 & $55-64$ & 3 & $15 \%$ & Kurang \\
\hline 5 & $0-54$ & - & - & \\
\hline & Total & $\mathbf{3 0}$ & $\mathbf{1 0 0 \%}$ & \\
\hline
\end{tabular}

Dari tabel 2 dari 30 siswa yang mengikuti tes di peroleh 9 orang siswa atau 35\% siswa dengan kategori "Sangat Baik", 18 orang siswa atau 50\% pada Kategori "Baik dan 3orang siswa atau 15\% pada kategori "kurang". Karena jumlah siswa yang memperoleh kategori minimal cukup baik sebanyak 27 orang siswa atau $100 \%$ dari 30 orang siswa yang mengikuti tes. Berdasarkan hasil tersebut penelitian ini diberhentikan. Dapat dicermati diagram batang dibawah ini yang menggambarkan hasil tes belajar siswa matematika pada siklus II sebagai berikut:

\section{Grafik 3 Tes Hasil Belajar Siswa Matematika}

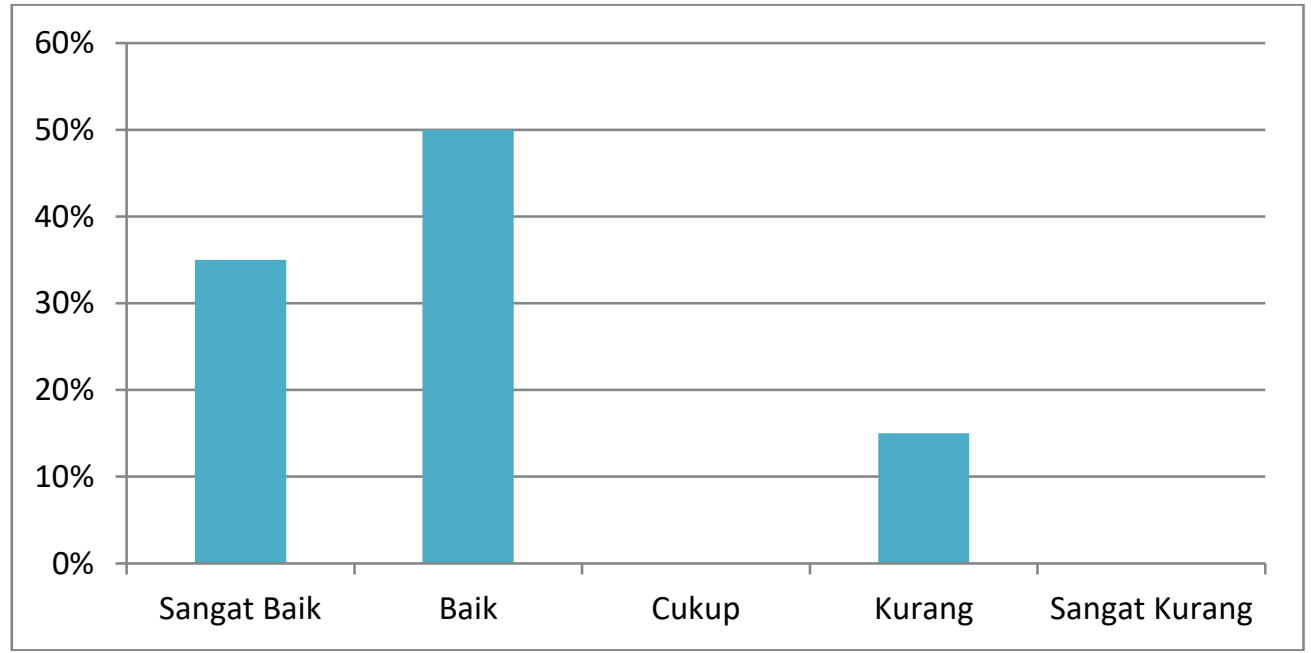

Hasil observasi dari kemampuan guru mengelola pembelajaran selama diberikan tindakan pada siklus I diperoleh kemampuan guru sebesar 83,3\% dengan kategori "Baik". Pada siklus II persentasenya meningkat menjadi 95\% dengan kategori "Sangat Baik". Hal ini berarti media elearning dapat meningkatkan kemampuan guru dalam mengelola pembelajaran.

\section{KESIMPULAN}

Berdasarkan tujuan penelitian, hasil penelitian dan pembahasan, maka penelitian yang dilaksanakan di kelas X SMK N 1 Batang Angkola Tahun Pelajaran 2020/2021 dapat di simpulkan bahwa kemampuan minat siswa dan kemampuan guru dalam mengelola penggunaan media berbasis e-learning pada pokok bahasan trigonometri di kelas X Tkj SMK N 1 Batang Angkola tahun pelajaran 2020/2021 meningkat pada setiap siklus. Pada masa pra siklus 15 siswa yang masuk tidak memenuhi KKM dengan rata-rata nilai 51,55. Hal ini dilihat dari hasil observasi kemampuan guru dalam mengelola pembelajaran pada siklus I memperoleh persentase 83,3\% dengan kategori "Baik" menjadi 95,8\% dengan kategori "Sangat Baik" pada siklus II. 


\section{REFERENSI}

Abdurrahman , Mulyono (2012). Anak kesulitan belajar. Jakarta: Rineka Cipta

Alfabeta (2012). Metode dan model-model pembelajaran. Bandung: Rajawali Pers

Annurahman. (2011). Belajar dan Pembelajaran.Bandung: Alfabeta.

Asmindanmansyur(1996).MediaPendidikan:Pengertian,Pengembangan,dan pemanfaatannya. Jakarta : PT. Raya Grafindo Persada

Aroson, Elliot. (2006). The jigsaw Classroom Web site Social Psycology Network. Oktober 2016. Vol. 3 No. 1 .

Arikunto,Suharsimi.( 2002).Dasar-dasar Evaluasi Pendidikan. Jakarta :Rineka Cipta

Effendi, Empy dkk.( 2005). E-learning konsep dan Aplikasi. Yogyakarta: Andi

Hanafia, Nanang dan Suhana, Cucu. (2009). Konsep Strategi Pembelajaran. Bandung: PT Z

Imas \& Berlin, (2015), Ragam Pengembangan Model Pembelajaran, Surabaya: Kata Pena.

Jurnal Pena Edukasi, Vol 3 No. 6, Nopember 2016

Lewis,( 2002). Lesson Study : A Handbook Of Teacher-lead intructional. Philadelphia PA: Rearch for Better Scholls.

Martin Jenkins And Janet hanson, Generic Center (2003), E-learning Saries: Guide For Senior manangers. LSTN Gerenic Center.

Rohmah , L. (2016). Konsep E-learning Dan Aplikasinya Pada Lembaga Pendidikan islam, Jurnal Study Annur . Vol. 3 Nomor 2.

Rustam. (2004) peneliti tindakan kelas. Jakarta: Bumi Aksara.

Sukardi (2010) Metodologi Penelitian Pendidikan Kompetensi, Jakarta : PT Bumi Aksara

Sanjaya Wina. Strategi Pembelajaran,Jakarta : Kencana Prenada Media Group.

SitiFatimah( 2009).Matematika Hakikat \& Logika, Jogjakarta: Ar-Ruzz Media Group.

Trianto. (2009). Pendesain Model Pembelajaran Inovatif Progresif: Kencana Predana Media Group.

Trianto.(2011). Model Pembelajaran Terpadu Konsep Strategi Dan Implementasinya Dalam Tingkat Satuan Pendidikan. Jakarta: Prestasi Pustaka

Walgito, Bimo. (2004) .Pengantar Psikologi Umum. Yogyakarta: Andi

Zaini, Hisyam dkk. (2008).Strategi Pembelajaran Aktif, Yogyakarta: Pustaka Insan 